Bangladesh J. Plant Taxon. 18(1): 69-71, 2011 (June)

- Short communication

(C) 2011 Bangladesh Association of Plant Taxonomists

\title{
MUHLENBERGIA FASCICULATA T.P.I. PHAN (POACEAE) - A NEW ANGIOSPERMIC RECORD FOR INDIA
}

\author{
D. Delmail ${ }^{1}$ and A. Hilaire \\ Laboratory of Botany and Cryptogamy, Faculty of Pharmacy, University of Limoges, \\ GRESE EA 4330, 2 rue du Docteur Marcland, FR-87025 Limoges, France
}

Keywords: Mulhenbergia fasciculata; New record; India.

Muhlenbergia Schreb. (Poaceae) is related to the genera Sporobolus R. Br. and Blepharoneuron Nash. The genus contains approximately 160 species (Herrera-Arrieta, 1998), and the majority of them are xeromorphic and caespitose, and inhabit steppes and mountains from subarctic North America to southern South America (Pohl, 1969) as well as southeast Asia (Zhenlan and Peterson, 2006). The species $M$. fasciculata was firstly described in 1994 in Myanmar and then was thought to be extinct due to habitat loss (Phan, 1994). However, one population was discovered in 2004 and 52 individuals have been confirmed in Arakan hills of western Myanmar in the Rakhine region on rocky environments at altitudes from 1000 to $1300 \mathrm{~m}$ about the sea level (Delmail, 2010).

More recently, a survey in the Nagaland state (India) brings to the discovery of 3 new isolated specimens, from a rocky open grassland at about $25 \mathrm{~km}$ northwest of Longwa. This is the first record of occurrence for India at the frontier with Myanmar.

A detailed taxonomic description and illustration of the taxon have been provided based on the examined wild specimens.

Muhlenbergia fasciculata T.P.I. Phan, Flora from the Gulf of Bengal 1: 158 (1994).

(Fig. 1)

Caespitose perennial, rhizomatous. Culms $45-56 \mathrm{~cm}$, erect or spreading. Leaf sheaths 2.1-3.0 cm long, glabrous, striate, often longer than the internodes, without hyaline margins; nodes densely puberulent. Ligules 0.4-0.6 $\mathrm{mm}$ long, membranous, hyaline, fimbriate, apex obtuse. Basal blades 7-13 cm long, 1.9-2.1 mm wide, flat, margins and midveins sclerosed, scabrous. Panicles 6-9 cm long, 3-5 cm wide, diffuse, pyramidal; primary branches $3-4 \mathrm{~cm}$ long, straight, capillary, diverging $73-95^{\circ}$ from the rachis; pedicels 2.4-7.5 mm long, scabrous; inflorescence branches 1-3 cm long. Spikelets 2-3.1 $\mathrm{mm}$ long, erect; glumes 0.8-1.6 mm long, acute, entire, sometimes longer than the lemma, usually equal in length, one-nerved, glabrous, yellowish; lemmas 1.5-2.4 mm long, lanceolate, hyaline, awned, glabrous; palea 1.2-1.8 $\mathrm{mm}$ long, oblanceolate, entire, glabrous; lodicules 2, hyaline; Anthers 3, yellowish to orange, 0.4-0.8 mm long; ovary glabrous; styles free to their bases. Caryopsis not observed.

${ }^{1}$ Corresponding author. E-mail: david.delmail@wanadoo.fr 

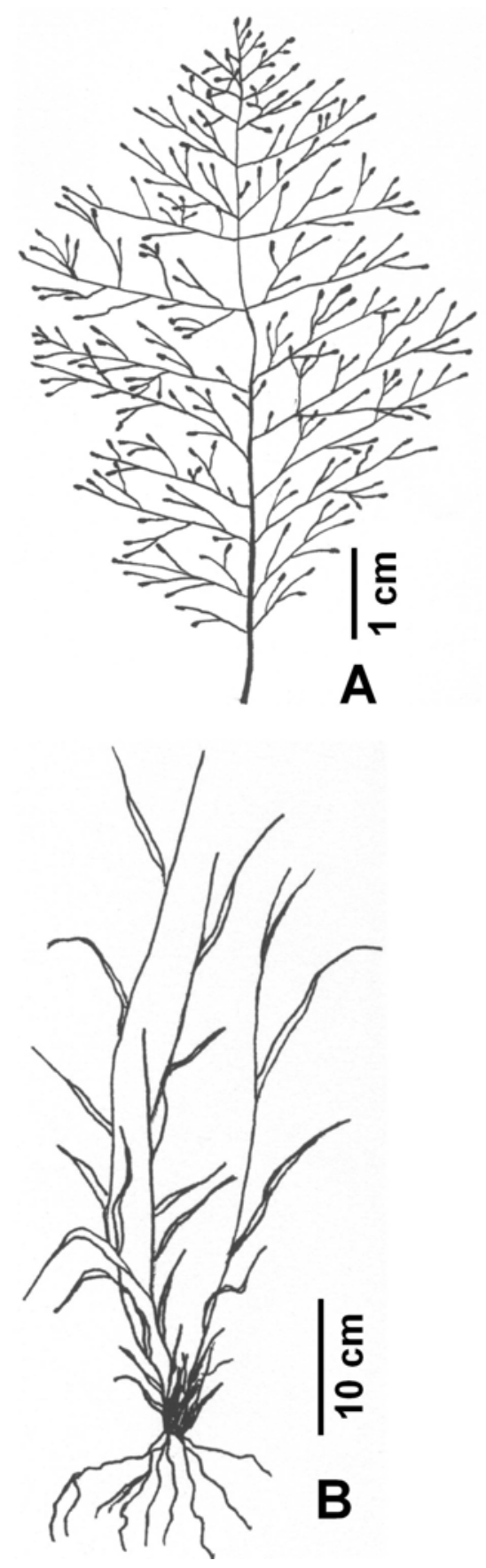
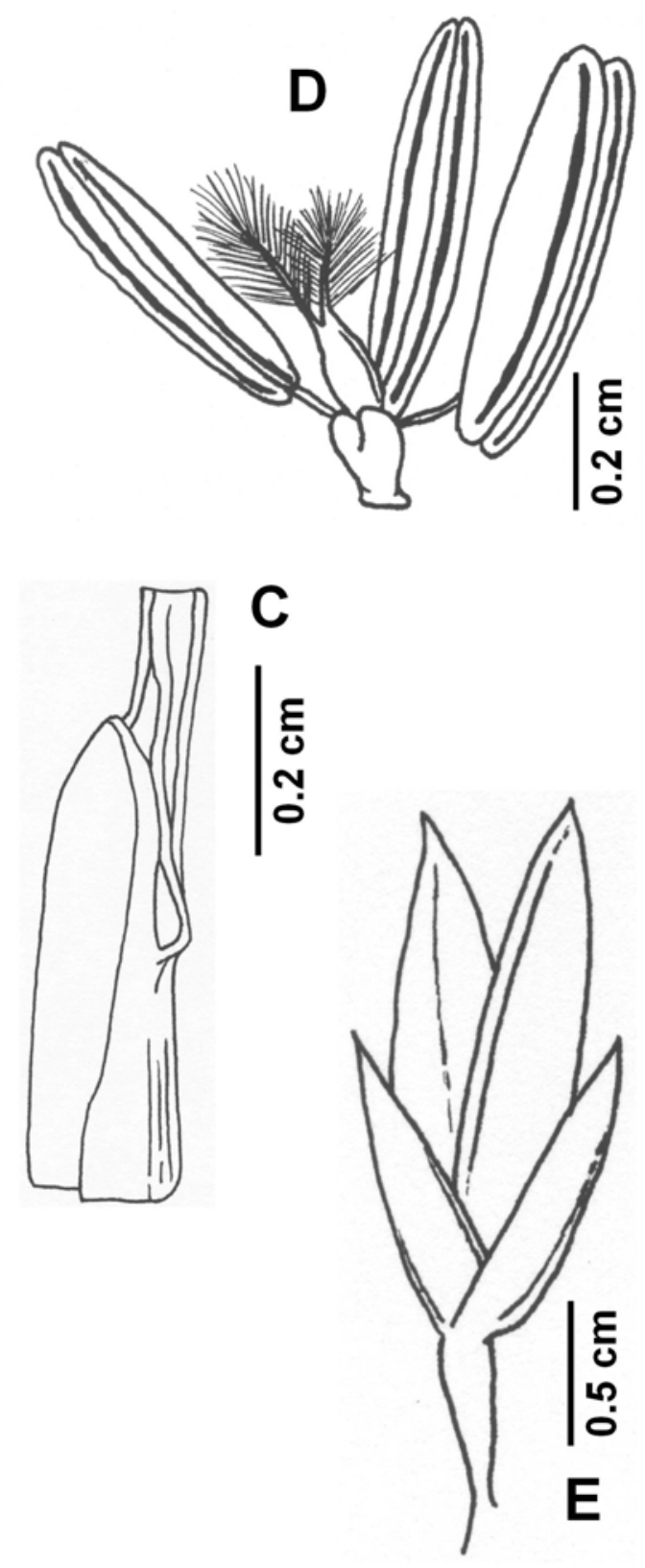

Fig. 1. Mulhenbergia fasciculata T.P.I. Phan. A. inflorescence, B. habit, C. ligule, D. lodicules, stamens and pistil, E. spikelet. 
Specimen examined: India, Nagaland state, Mon district, about $25 \mathrm{~km}$ northwest of Longwa, 28 ${ }^{\circ} 7^{\prime} 56^{\prime \prime} \mathrm{N}, 97^{\circ} 0^{\prime} 10^{\prime \prime}$ E, 850-900 m, 10.06.2006, Shott W., Delmail D. and Hilaire A. (no specimen was collected due to the low number of individuals (3) in the population and its weak occurrence in the wild).

Ecology: On open grasslands (Phan, 1994) and rocky open grasslands. In these environments, many plant species occur. Among them, typical Poaceae are observed as Cymbopogon citratus, Cymbopogon martinii and Neyraudia reynaudiana. Shrubs are constituted with Rhododendron cerasinum, Rhododendron pruniflorum and Rhododendron repens. Other species as Allium sp., Arenaria sp., Cremanthodium farreri, Meconopsis sp., Omphalogramma burmanica and Primula sp. form cushions.

Distribution: Initially native to Myanmar but now found in India.

\section{Acknowledgements}

This work has been supported by the National Botanical Conservatory of Brest (CBNB) and the Conseil Régional du Limousin. Authors thank J.-Y. Lesouëf (CBNB) and $\mathrm{Wu}$ Shott for valuable discussions and support during fieldwork.

\section{References}

Delmail, D. 2010. Validation of Muhlenbergia fasciculata (Poaceae) endemic to Myanmar. Nord. J. Bot. 28: 298.

Herrera-Arrieta, Y. 1998. A revision of the Muhlenbergia montana (Nutt.) Hitchc. complex (Poaceae: Chloridoideae). Brittonia 50: 23-50.

Phan, T.P.I. 1994. Flora from the Gulf of Bengal. XUKJ Press, Khaoni, pp. 1-387.

Pohl, R.W. 1969. Muhlenbergia subgenus Muhlenbergia (Gramineae) in North America. Am. Midl. Nat. 82: 512-542.

Zhenlan, W. and Peterson, P.M. 2006. Muhlenbergia. Flora of China 22: 486-487. 